Volume4 : Issue 1, October, 2020

\title{
Professional Laboratory Safety Practice of Basic Science Teachers in Gaza Strip
}

Maher Elbayoumi ${ }^{1}$

${ }^{1}$ Energy and Sustainable Environment Center, School of Engineering, Israa University, Gaza, Palestine.

Email: elbayoumimaher@gmail.com

\begin{abstract}
A lot of accidents occur in the laboratory due to lack of proper knowledge regarding laboratory safety measures \& improper implementation of safe laboratory practices. A cross-sectional descriptive study was conducted to assess the level of laboratory safety concepts practice among Palestinian science teachers by using a structured questionnaire. The sample of the study included 58 school science teachers in Middle Governorate, Gaza Strip. Results indicate that the participants had a good understanding of chemicals and therefore displayed safe handling, storage, and usage. Although there are clear requirements and an obligation to adhere to standard precautions, these measures were poorly practiced by science teachers in using protection glasses 48.0\%, in consulting Material Safety Data Sheet (MSDS) for disposal information $52.0 \%$ and in wearing lab mask $48.0 \%$. Moreover, results showed that surveyed laboratories were lack of fire blanket 55.8\% and safety shower 90.9\%. Despite the educational and training program for science teachers, safety practice and associated issues remained inadequate. The study recommended that the Educational Department needs to create a specialized division to design and follow up the occupational safety, focus on training teachers to promote awareness, and develop their skills.
\end{abstract}

Keywords: Chemical education; Safety; Hazardous materials; Teaching 
Volume4 : Issue 1, October, 2020

\section{Introduction}

Science is a way of discovering and questioning life and how those things work today, how they worked in the past, and how they are likely to work in the future (Kouzov \& Pavlova, 2016). The school science laboratory as a unique learning environment has been given a central and distinctive role in which students develop their understanding of scientific concepts, science inquiry skills, perceptions of science, enable collaborative social relationships as well as positive attitudes toward science and cognitive growth (Gunstone, 1991; Lazarowitz \& Tamir, 1994; Lunetta, 1998).

Interestingly, it has been found that studies that focus on science laboratories in the educational area mainly deal with the materials, methods, and technics. Unfortunately, there has been limited attention to safety issues (Akpullukcu \& Cavas, 2017). The vast majority of school laboratories can be insecure for staff and students due to usage of chemicals that may be either themselves hazardous, or become hazardous because of some chemical reaction. It is necessary, therefore, to identify hazards, and assess and control potential risks, in order on the one hand to provide a safe working environment for employees, and on the other hand to prevent any potential damage to the wider environment (Malik et al., 2016).

Often, accidents occur due to misunderstanding or lack of proper knowledge to interpret the labelling of the chemicals (WHO, 2009; Wiediger \& Hutchinson, 2002). Moreover, Stephenson et al. (2003) study discovered that one third of science teachers did not have a written safety policy and did not receive adequate safety training. However, a critical factor that may lead to an accident, not as a result of restricted information but because a safety procedure turns into a daily practice, routine, and individuals relax their precautions. Laboratory safety is not simply the outcome of a strict adherence to regulations; it is also the result of an overall attitude and commitment (Versweyveld, 1999; Walker, 1999).

Handling chemical substances without proper precautions exposes the students and teachers to the risk of absorbing harmful amounts of chemicals through the skin. Hagelberg and Dombrowski (1987) study found that over one-fifth of all science teachers in USA had a student suffer from a serious injury during the experiment activity, one requiring a physician's care at some time during their career. According 


\section{Volume4 : Issue 1, October, 2020}

to Gerlovich et al. (2001) study, most the accidents and injuries that occurred in the laboratories are caused by the broken glassware and chemical exposure. Most accidents involve burns from handling hot objects, contact with corrosive chemicals, or cuts from broken glassware and from attempts to insert glass tubing into rubber stoppers (Gerlovich et al., 1998; Ward \& West, 1990). Due to the misuse of the chemicals at schools levels teachers and students face a lot of problems regarding the health impact such as eye irritation, headache, dizziness, nausea and respiratory disorders (Collins et al., 2013; Reisen \& Brown, 2009) .

During the lessons, teachers are planning the activities, providing careful directions before allowing students to attempt independent projects, protecting the health welfare and safety of their students, reporting all hazardous conditions, and being present in the laboratory to ensure adequate safety supervision (Olson \& Loucks, 2000).Thus, teachers does not share with their students just empirical data but their own vision and way to critically understand the facts that are considered. Students are very likely to develop favourable knowledge and skills towards the impact of chemicals in their personal and public lives if teachers have appropriate cognition, skills and behaviour when teaching about and handling chemicals in the course of teaching basic science (Joshua, 2004; Peñas et al., 2006).Thus, it is important to create an environment in which appropriate laboratory behaviour is maintained.

Excellence in teaching requires safe science investigations in the class room and laboratory. As teachers responsibilities include not only safety related with the science laboratories but also for every chemical or material they bring into or accept in their classroom. Important information about handling chemicals can be found in the Material Safety Data Sheet (MSDS) which is available for all chemicals. Thus, teachers must know what each is, what it can do, and how it should be stored. Teachers should be informed about all safety issues which include biological and animal hazards, blood-borne pathogens, chemicals, electrical safety, handling glassware, fire control, labelling, and eye and face protection (Akpullukcu \& Cavas, 2017).

In Gaza strip, Palestine, the educational system has implemented several regulations and provided schools with fire exchanger and first aids equipment's. Therefore every school must has its own safety plan and school administration is required to report 


\section{Volume4 : Issue 1, October, 2020}

about any type of accidents. As accidents may happen suddenly, the teacher should be well prepared in the front line of defence to prevent laboratory injuries for such cases. Therefore, it is important to have an understanding about science teachers' knowledge and understanding about laboratory safety responsibilities. So this present study was conducted to investigate the knowledge and practice of teachers regarding safety measures in laboratory.

\section{Methods}

The researcher developed a two-part questionnaire adapted from the literature were developed. Part 1 of the questionnaire collected demographic data for all respondents. In Part 2 of the questionnaire respondents were asked about their knowledge and practice during their duties about laboratory safety and if they had access to various items of Personal Protective Equipment's (PPE) in their educational settings and whether they ever had the opportunity to use various safety engineered devices. To check the validity of the questionnaire, the questionnaire was distributed in March 2018 to a group of experts with different back grounds (Education and Science fields) and a pilot study consisting of 30 teacher was carried to measure the reliability of the questionnaire. The Alpha Cronbach (0.818) and the split-half techniques (0.868) results confirmed the reliability.

\section{Study Sample:}

In Gaza Strip there are 531 science laboratories in both of Governmental and United Nations Relief and Works Agency for Palestine Refugees in the Near East (UNRWA) schools that serve 576951 students. In Middle Governorate, UNRWA operate 59 schools which have 37 science laboratory and serve 57263 students (MOE, 2019). The population of the study was all UNRWA schools science teachers (103) working in Middle Governorate in Gaza Strip. From a group of 103 teachers, 58 successfully completed the questionnaires (overall response rate $56.3 \%$ ). 
Volume4 : Issue 1, October, 2020

\section{Data Analysis:}

All the gathered data were classified and tabulated as per the nature of the data. Data were analyzed by using descriptive and inferential statistics i.e. percentages and ANOVA and t-Tests through the SPSS Version 21.

\section{Results and Discussion}

\section{1- Demographic characteristics of science teachers}

There were 29 male teachers (50\%), and 29 female teachers (50\%). Most of the respondents have teaching experiences from 6-15 years in the field with rate (60\%) as shown in Table 1.

Table 1: Demographic characteristics of science teachers

\begin{tabular}{|l|l|l|l|}
\hline \multicolumn{2}{|c|}{ Variable } & Number & \multicolumn{1}{c|}{$\begin{array}{l}\text { Percentage } \\
\text { \% }\end{array}$} \\
\hline \multirow{2}{*}{ Gender } & Male & 29 & 50.0 \\
\cline { 2 - 4 } & Female & 29 & 50.0 \\
\hline \multirow{2}{*}{ Job Description } & Teacher & 49 & 84.5 \\
\cline { 2 - 4 } & Lab supervisor & 9 & 15.5 \\
\hline \multirow{3}{*}{$\begin{array}{l}\text { Experience } \\
\text { Years }\end{array}$} & 1-5 years & 16 & 28 \\
\cline { 2 - 4 } & 6-15 years & 75 & 60 \\
\cline { 2 - 4 } & More than 16 years & 7 & 12 \\
\hline
\end{tabular}

\section{2- Level of safety practice for up keeping of laboratory and equipment}

The results of practice about various aspects of up keeping of laboratory and equipment indicated that $95.4 \%$ of the respondents notified the administration in writing if a hazardous or possibly hazardous condition (e.g., malfunctioning safety equipment or chemical hazard) was identified in the laboratory. The high commitments among teachers is due to the restricted safety policy that established in UNRWA schools. In addition to that $83.1 \%$ of respondents indicated that the inspections of presence and validity of safety and first aid equipment were conducted regularly as requested by the schools administration as shown in Table 2. However, $48.0 \%$ of respondents wear mask before doing experiment activities inside the laboratory and $41.8 \%$ wear shoes that don't cover part of my feet (sandal) while I'm doing experiments in the lab. 
Volume4 : Issue 1, October, 2020

Table 2: Level of safety practice for up keeping of laboratory and equipment

\begin{tabular}{|c|c|c|c|c|c|c|}
\hline Questions & Mean & $\begin{array}{l}\text { Standard } \\
\text { Deviation }\end{array}$ & $\begin{array}{c}\text { Parentage } \\
\%\end{array}$ & t- test & Sig & Rank \\
\hline $\begin{array}{l}\text { I inform the } \\
\text { administratio } \\
\mathrm{n} \text { about } \\
\text { hazardous } \\
\text { condition if it } \\
\text { was identified } \\
\text { in the } \\
\text { laboratory }\end{array}$ & 4.74 & 0.52 & 95.4 & 29.66 & .001 & 1 \\
\hline $\begin{array}{l}\text { I inspect the } \\
\text { validity of } \\
\text { safety and } \\
\text { first aid } \\
\text { equipment } \\
\text { regularly }\end{array}$ & 4.16 & 1.09 & 83.1 & 10.05 & .001 & 2 \\
\hline $\begin{array}{l}\text { I wear a } \\
\text { laboratory } \\
\text { coat to } \\
\text { protect my } \\
\text { clothes } \\
\text { during lab } \\
\text { activities }\end{array}$ & 3.31 & 1.32 & 66.2 & 2.23 & .028 & 3 \\
\hline $\begin{array}{l}\text { I wear } \\
\text { protection } \\
\text { glasses when } \\
\text { using } \\
\text { chemicals }\end{array}$ & 2.40 & 1.28 & 48.0 & -4.42 & .001 & 5 \\
\hline $\begin{array}{l}\text { I wear gloves } \\
\text { when using } \\
\text { chemicals }\end{array}$ & 2.89 & 1.29 & 57.8 & -0.86 & .394 & 4 \\
\hline $\begin{array}{l}\text { I wear mask } \\
\text { before doing } \\
\text { experiment } \\
\text { activities } \\
\text { inside the } \\
\text { laboratory. }\end{array}$ & 2.40 & 1.28 & 48.0 & -4.42 & .001 & 5 \\
\hline $\begin{array}{l}\text { I wear shoes } \\
\text { that don't } \\
\text { cover part of } \\
\text { my feet } \\
\text { (sandal) } \\
\text { while I'm } \\
\text { doing } \\
\text { experiments } \\
\text { in the lab }\end{array}$ & 2.09 & 1.26 & 41.8 & -6.81 & .001 & 6 \\
\hline $\begin{array}{l}\text { I use the } \\
\text { pipette to } \\
\text { draw samples } \\
\text { of chemicals } \\
\text { by mouth }\end{array}$ & 1.88 & 1.28 & 37.6 & -8.27 & .001 & 7 \\
\hline $\begin{array}{l}\text { Whole } \\
\text { domain }\end{array}$ & 2.98 & 1.17 & 59.73 & 8.34 & $\begin{array}{c}0.05 \\
1 \\
\end{array}$ & \\
\hline
\end{tabular}


Volume4 : Issue 1, October, 2020

\section{3- Safety and Emergency Procedures}

Personal protective equipment (PPE) is an important component in hazard control strategies. With regard to respondents' practice toward using PPE, about $66.2 \%$ wore laboratory coat and $57.8 \%$ wore gloves when dealing with chemicals and lab activities. The observation showed good compliance to use PPE such as wearing gloves and lab coat. However, poor compliance of using other PPE were common among respondent teachers. $48.0 \%$ of respondent only reported that they used protection glasses wore mask before doing experiment activities. Moreover, $41.8 \%$ teachers reported that they wore shoes that did not cover part of their feet (sandal) and $37.6 \%$ of them used the pipette to draw samples of chemicals by their mouth. In this study, all teacher received training about standard precautions. Hence, much work needs to be carried out to educate them on the need for standard precautions and to ensure that adherence to standard precautions is monitored. According to literatures, the degree of compliance with some basic standard precautions by workers was monitored. The researchers concluded that one of the factors that can contribute to noncompliance is time limitation - staff having to work in a hurry because shifts follow each other closely (Arenas et al., 2005; El-Enein \& El Mahdy, 2011).

Respondents were asked about laboratory safety components and their duties regarding safety rules, evacuation plan and first aid knowledge as shown in Table 3. On average $87.9 \%$ of respondent teachers reported that they mentioned safety precautions and devoted part of the class period to safety or tested students on safety. This is considered as one of the teachers obligations toward students to instruct their students in the basic safety practices required in science laboratories and in the basic principles of health hazards that are found in school science laboratories ( Brundage \& Palassis 2006) .

When those respondents were questioned further about availability of warnings of biological and chemical hazards signs $72.9 \%$ knew about it. It was also found that $77.1 \%$ knew special procedures for dealing with toxic and dangerous chemicals. Furthermore, $87.4 \%$ of the respondents had access to the first aid kit and conducted appropriate safety and evacuation drills on a regular basis. The safety inspection by the schools administration regarding the safe use of chemicals is one of the obligation policies in UNRWA schools in Gaza Strip. The result of this study is in contrast of 


\section{Volume4 : Issue 1, October, 2020}

Gerlovich et al. (2001) study which revealed that $48 \%$ of Nebraska surveyed teachers indicated that safety inspections in their schools were not conducted .

Table 3 also presents a variation in respondents' knowledge regarding using a fire extinguisher or fire blanket. $81 \%$ of teachers knew about using a fire extinguisher in the event of a fire at the training site and 55.8\% didn't have fire blanket in the laboratory. In terms of knowledge regarding first aid knowledge when dealing with chemical accidents, the highest number $(88 \%)$ reported that they knew what to do if a chemical enters their eye. However, $90.9 \%$ of the respondents confirmed that they do not have safety showers which is a crucial component of safety equipment. Thus, the absence of safety showers in school laboratories needs to be addressed. In conclusion, the general mean of the domain of safety and emergency procedures was 4.07 in percentage of $81.48 \%$ which consider acceptable.

Table 3: Safety and Emergency Procedures

\begin{tabular}{|c|c|c|c|c|c|c|}
\hline Questions & Mean & $\begin{array}{l}\text { Standard } \\
\text { Deviation }\end{array}$ & $\begin{array}{l}\text { Parentage } \\
\%\end{array}$ & t- test & Sig & Rank \\
\hline $\begin{array}{l}\text { Educate students } \\
\text { on the location } \\
\text { and use of all } \\
\text { safety and } \\
\text { emergency } \\
\text { equipment prior to } \\
\text { laboratory activity }\end{array}$ & 4.39 & 0.698 & 87.9 & 18.87 & .001 & 5 \\
\hline $\begin{array}{l}\text { Identify safety } \\
\text { procedures to } \\
\text { follow in the } \\
\text { event of an } \\
\text { emergency/accide } \\
\text { nt. }\end{array}$ & 4.44 & 0.795 & 88.9 & 17.24 & .001 & 3 \\
\hline $\begin{array}{l}\text { Provide students } \\
\text { with verbal safety } \\
\text { procedures to } \\
\text { follow in the } \\
\text { event of an } \\
\text { emergency/accide } \\
\text { nt }\end{array}$ & 4.51 & 0.782 & 90.2 & 18.32 & .001 & 2 \\
\hline $\begin{array}{l}\text { Know the location } \\
\text { of and how to use } \\
\text { all safety and } \\
\text { emergency } \\
\text { equipment }\end{array}$ & 4.39 & 0.698 & 87.8 & 18.87 & .001 & 6 \\
\hline $\begin{array}{l}\text { know about using } \\
\text { a fire extinguisher } \\
\text { in the event of a } \\
\text { fire at the training }\end{array}$ & 4.03 & 1.156 & 81 & 8.48 & .001 & 7 \\
\hline $\begin{array}{l}\text { School laboratory } \\
\text { has a fire blanket }\end{array}$ & 2.29 & 1.274 & 44.2 & -5.29 & .001 & 11 \\
\hline
\end{tabular}


Volume4 : Issue 1, October, 2020

\begin{tabular}{|c|c|c|c|c|c|c|}
\hline $\begin{array}{l}\text { Conduct } \\
\text { appropriate safety } \\
\text { and evacuation } \\
\text { drills on a regular } \\
\text { basis }\end{array}$ & 4.36 & 0.865 & 87.4 & 14.86 & .001 & 8 \\
\hline $\begin{array}{l}\text { In the laboratory } \\
\text { there are signs } \\
\text { and warnings of } \\
\text { biological and } \\
\text { chemical hazards }\end{array}$ & 3.64 & 1.310 & 72.9 & 4.67 & .001 & 10 \\
\hline $\begin{array}{l}\text { There are special } \\
\text { procedures for } \\
\text { dealing with toxic } \\
\text { and dangerous } \\
\text { chemicals }\end{array}$ & 3.86 & 1.034 & 77.1 & 7.85 & .001 & 9 \\
\hline $\begin{array}{l}\text { I know what I } \\
\text { should do if a } \\
\text { chemical enters } \\
\text { my eye } \\
\end{array}$ & 4.40 & 0.667 & 88.0 & 19.91 & .001 & 4 \\
\hline $\begin{array}{l}\text { Safety shower is } \\
\text { not installed in } \\
\text { school laboratory }\end{array}$ & 4.54 & 0.796 & 90.9 & 18.42 & .001 & 1 \\
\hline Whole domain & 4.07 & 0.915 & 81.48 & 13.88 & $\begin{array}{l}\mathbf{0 . 0 0} \\
1\end{array}$ & \\
\hline
\end{tabular}

\section{4- Maintenance of Chemicals and using of MSDS}

According to World Health Organization (WHO) report, the major sources of chemical injuries worldwide were due to unsafe use of chemicals, lack of information on risks and education on their safe and wise use and lack of appropriate regulatory measures or the impossibility of enforcing them (WHO, 2009). Therefore; most of the surveyed teachers had a good knowledge and practice in this issue where $73.6 \%$ of them performed regular inventory inspections of chemicals and $86.2 \%$ of them kept all chemicals in their original containers and make sure all chemicals and reagents are labelled. In addition to that $90.8 \%$ of them had a good knowledge about the storage, handling and disposal requirements for each chemical used and ensure chemicals not in use are stored in a locked facility with limited access. Moreover, $86.2 \%$ of the surveyed teachers ensured that hazardous chemicals had labels to identify their toxicity and flammability which can be impairment of indoor air quality and cause acute and chronic health hazards as shown in Table 4. Good practices were observed regarding the chemical labelling, storage and chemical inventory. Stallings et al. (2001) study suggested that all chemicals should be labelled with their chemical name 


\section{Volume4 : Issue 1, October, 2020}

and formula and they must be placed in their specific places to reduce the health hazards.

The Occupational Safety and Health Administration (OSHA) estimates that there are 575,000 hazardous chemical products in American workplaces. The adverse effects of these chemicals are acute toxicity, irritation, corrosion, sensitization, carcinogenicity, reproductive toxicity, and so on (Seki et al., 2001). The MSDS was defined as one of the fundamentals for protection of workers from the harmful effects of chemicals. Thus, $48.0 \%$ of the respondents used to consult the label and MSDS for disposal information and used to follow appropriate chemical disposal regulations as shown in Table 4. More than half the respondent teachers were unaware of MSDS which indicating a lack of training and explicit awareness at organizational level. It may also indicate a need to include chemical management education in the pre- service and in service teacher training programs by responsible institutions. It is obligatory for the school administration to provide the guidelines to science teachers about the nature, properties, classification labelling, transport and storage of chemicals before the performance of practical task for the safe use of chemicals and to minimize the risk of chemical injuries. Stallings et al. (2001) study reported that by providing safety training to the teachers including use of MSDS will help to reduce the chemical hazards in the laboratory. In conclusion, the general mean of the domain of maintenance of chemicals and using of MSDS was 4.07 in percentage of $80.51 \%$. This percentage considers acceptable.

Table 4: Maintenance of Chemicals and using of MSDS

\begin{tabular}{|l|c|c|c|c|c|c|}
\hline Questions & Mean & $\begin{array}{l}\text { Standard } \\
\text { Deviation }\end{array}$ & $\begin{array}{c}\text { Parentage } \\
\text { \% }\end{array}$ & t- test & Sig & Rank \\
\hline $\begin{array}{l}\text { Perform } \\
\text { regular } \\
\text { inventory } \\
\text { inspections of } \\
\text { chemicals }\end{array}$ & 3.84 & 1.348 & 73.6 & 5.94 & 5 \\
\hline $\begin{array}{l}\text { Update the } \\
\text { chemical } \\
\text { inventory at } \\
\text { least annually, } \\
\text { or as } \\
\text { requested by } \\
\text { the } \\
\text { administration } \\
\text { r }\end{array}$ & 3.84 & 1.348 & & & & \\
\end{tabular}


Volume4 : Issue 1, October, 2020

\begin{tabular}{|c|c|c|c|c|c|c|}
\hline $\begin{array}{l}\text { Do not store } \\
\text { food and } \\
\text { drink with any } \\
\text { chemicals. }\end{array}$ & 4.64 & 0.526 & 92.9 & 29.66 & .001 & 1 \\
\hline $\begin{array}{l}\text { If possible, } \\
\text { keep all } \\
\text { chemicals in } \\
\text { their original } \\
\text { containers. }\end{array}$ & 4.36 & 0.865 & 86.2 & 14.86 & .001 & 4 \\
\hline $\begin{array}{l}\text { Make sure all } \\
\text { chemicals and } \\
\text { reagents are } \\
\text { labeled. }\end{array}$ & 4.36 & 0.865 & 86.2 & 14.86 & .001 & 4 \\
\hline $\begin{array}{l}\text { Do not store } \\
\text { chemicals on } \\
\text { the lab bench, } \\
\text { on the floor, } \\
\text { or in the } \\
\text { laboratory } \\
\text { chemical } \\
\text { hood. }\end{array}$ & 4.36 & 0.865 & 87.1 & 14.86 & $\begin{array}{l}.0 \\
0 \\
1\end{array}$ & 3 \\
\hline $\begin{array}{l}\text { Ensure } \\
\text { chemicals not } \\
\text { in use are } \\
\text { stored in a } \\
\text { locked facility } \\
\text { with limited } \\
\text { access. }\end{array}$ & 4.36 & 0.865 & 86.2 & 14.86 & $\begin{array}{l}.0 \\
0 \\
1\end{array}$ & 4 \\
\hline $\begin{array}{l}\text { Know the } \\
\text { storage, } \\
\text { handling, and } \\
\text { disposal } \\
\text { requirements } \\
\text { for each } \\
\text { chemical } \\
\text { used. }\end{array}$ & 4.52 & 0.824 & 90.8 & 17.52 & $\begin{array}{l}.0 \\
0 \\
1\end{array}$ & 2 \\
\hline $\begin{array}{l}\text { Consult the } \\
\text { label and the } \\
\text { Material } \\
\text { Safety Data } \\
\text { Sheet for } \\
\text { disposal } \\
\text { information } \\
\text { and always } \\
\text { follow } \\
\text { appropriate } \\
\text { chemical } \\
\text { disposal } \\
\text { regulations. }\end{array}$ & 2.40 & 1.288 & 48.0 & -4.42 & $\begin{array}{l}.0 \\
0 \\
1\end{array}$ & 6 \\
\hline $\begin{array}{l}\text { Whole } \\
\text { domain }\end{array}$ & 4.07 & 0.97 & 80.51 & 13.65 & 0.001 & \\
\hline
\end{tabular}


Volume4 : Issue 1, October, 2020

\section{5- Preparing for Laboratory Activities}

Preparing for the lessons and labs activities are very important skills that teachers must have during lesson planning. Moreover, science teachers that consider the safety issues before laboratory activities and weigh the potential risk factors against the educational value have fewer accidents. Papanastasiou (2001) study affirms that teacher's role during the learning process can directly or indirectly influence student attitude and hence student learning outcomes. Thus, $90.2 \%$ of the science teachers who surveyed had an understanding of all the potential hazards of the materials, the process, and the equipment involved in every laboratory activity and inspected all equipment/apparatus in the laboratory. In addition to that $96 \%$ of respondents instructed students on all laboratory procedures and discussed all safety concerns and potential hazards related to the laboratory work before starting the work. World Health Organization strongly emphasize that good chemical safety habits early, better prepare students to learn how to work safely and develop their individual sense of responsibility and good habits for the safe handling and use of chemicals (WHO, 2004).

In conclusion, the general mean of the domain of preparing for laboratory activities was 4.67 in percentage of $93.1 \%$. This percentage consider acceptable.

Table 5: Preparing for Laboratory Activities

\begin{tabular}{|l|l|l|l|l|l|l|}
\hline Questions & Mean & $\begin{array}{l}\text { Standard } \\
\text { Deviation }\end{array}$ & $\begin{array}{l}\text { Parentage } \\
\text { \% }\end{array}$ & t- test & Sig & Rank \\
\hline $\begin{array}{l}\text { Have an } \\
\text { understanding of all } \\
\text { the potential } \\
\text { hazards of the } \\
\text { materials, the } \\
\text { process, and the } \\
\text { equipment involved } \\
\text { in every laboratory } \\
\text { activity. }\end{array}$ & 4.51 & 0.782 & 90.2 & 18.32 & .001 & 2 \\
\hline $\begin{array}{l}\text { Inspect all } \\
\text { equipment/apparatu } \\
\text { s in the laboratory } \\
\text { before use. }\end{array}$ & 4.51 & 0.782 & 90.2 & 18.32 & .001 & 2 \\
\hline $\begin{array}{l}\text { Before entering the } \\
\text { laboratory, instruct } \\
\text { students on all } \\
\text { laboratory proce- } \\
\text { dures that will be } \\
\text { conducted. }\end{array}$ & 4.84 & 0.326 & 96.0 & 30.0 & & .001 \\
\hline $\begin{array}{l}\text { Discuss all safety } \\
\text { concerns and } \\
\text { potential hazards }\end{array}$ & 4.84 & 0.326 & 96.0 & 30.0 & 1 \\
\hline
\end{tabular}


Volume4 : Issue 1, October, 2020

related to the laboratory work that students will be performing before starting the work. Document in lesson plan book.

Whole domain

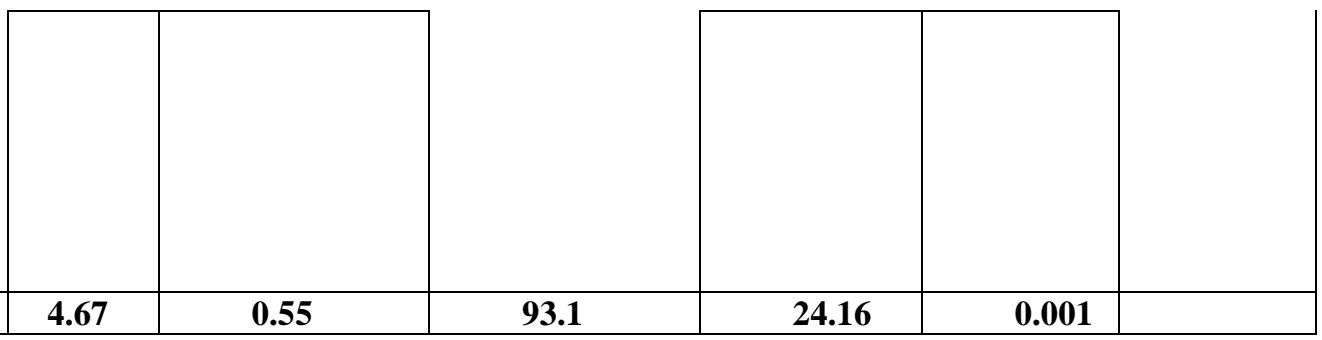

It is worth noting that when comparing the mean of the safety issues among science teacher by gender and job description, no statistical difference was noted $(\alpha<0.05)$ by using $\mathrm{T}$ test as shown in Table 6.

Table 6: The difference in mean of safety issues and chemical management among teachers using $T$ test.

\begin{tabular}{|l|l|l|l|l|}
\hline \multirow{2}{*}{ Variables } & \multicolumn{3}{|c|}{ Teacher responsibilities } \\
\cline { 2 - 4 } & $\begin{array}{l}\text { Record } \\
\text { keeping }\end{array}$ & $\begin{array}{l}\text { Safety and } \\
\text { Emergency } \\
\text { Procedures }\end{array}$ & $\begin{array}{l}\text { Maintenance } \\
\text { of } \\
\text { Chemicals }\end{array}$ & $\begin{array}{l}\text { Preparing for } \\
\text { Laboratory } \\
\text { Activities }\end{array}$ \\
\hline Gender & $0.5^{*}$ & $0.4^{*}$ & $0.25^{*}$ & $0.025^{*}$ \\
\hline $\begin{array}{l}\text { Job } \\
\text { Description }\end{array}$ & $0.46^{*}$ & $0.38^{*}$ & $0.22^{*}$ & $0.37^{*}$ \\
\hline
\end{tabular}

* mean p value

Different studies reported that teachers with less experience had more accidents and had less information about safety issue in schools (Pisaniello et al., 2013; Young, 1970). This may be due to insufficient familiarity with the facilities and/or classroom management. In our study there are no differences between the respondent teachers regarding there years of experiences and the knowledge they have because most of lab safety regulations in UNRWA schools are mandated as shown in Table (7). This finding is in accordance with Plohocki (1998) study.

Table 7. The difference in mean of safety issues and chemical management among teachers using One WAY ANOVA test

\begin{tabular}{|c|c|c|c|c|}
\hline \multirow[b]{2}{*}{ Variables } & \multicolumn{4}{|c|}{ Teacher responsibilities } \\
\hline & $\begin{array}{l}\text { Record } \\
\text { keeping }\end{array}$ & $\begin{array}{l}\text { Safety and } \\
\text { Emergency } \\
\text { Procedures }\end{array}$ & $\begin{array}{l}\text { Maintenance } \\
\text { of } \\
\text { Chemicals }\end{array}$ & $\begin{array}{l}\text { Preparing for } \\
\text { Laboratory } \\
\text { Activities }\end{array}$ \\
\hline $\begin{array}{l}\text { Years of } \\
\text { experience }\end{array}$ & $2 *$ & $2.4^{*}$ & $0.9^{*}$ & $0.4^{*}$ \\
\hline
\end{tabular}

* mean $\mathrm{p}$ value 
Volume4 : Issue 1, October, 2020

\section{CONCLUSION}

The findings indicate that the majority of the participants of the study had a high level of knowledge and a practice toward safe use of chemicals, personal protective environment, and storage \& labelling of chemicals. Although there is a clear requirement and an obligation to adhere to standard precautions, these measures were poorly practiced by science teachers. The results show that $48 \%$ of the respondents only used protection glasses and mask inside the lab and $37.6 \%$ of them used pipette to draw samples of chemicals by their mouth. Moreover, the study has found that most of the laboratory lack of fire blanket and safety shower $55.8 \%$ and $90.9 \%$; respectively. Furthermore, $52.0 \%$ of the respondents did not consult the label and MSDS for disposal information. Hence, the science teacher may ensure that a copy of the Material Safety Data Sheet (MSDS) for each chemical is present at the site and available for review and strict implementation of waste management rules is needed. As a summary there are many things to do in this area such as:

-Teacher preparation and in-service training should include both in-depth subject matter and safety instruction.

-Schools should have an enforced written lab safety policy.

-All science laboratories should be adequately ventilated to assure a minimum ventilation therefore fume hood is essential. 


\section{Volume4 : Issue 1, October, 2020}

\section{References}

1. Akpullukcu, S., \& Cavas, B. (2017). The Development of Laboratory Safety Questionnaire for Middle School Science Teachers. Science Education International, 28(3), 224-231.

2. Arenas, M. D., Sánchez-Payá, J., Barril, G., García-Valdecasas, J., Gorriz, J. L., Soriano, A., ... \& Espinosa, M. (2005). A multicentric survey of the practice of hand hygiene in haemodialysis units: factors affecting compliance. Nephrology Dialysis Transplantation, 20(6), 1164-1171.

3. Brundage, P., \& Palassis, J. (2006). School Chemistry Laboratory Safety Guide. Centers for Disease Control and Prevention. https://www.cdc.gov/niosh/docs/2007-107/pdfs/2007107.pdf?id=10.26616/NIOSHPUB2007107

4. Collins, J. J., Bodner, K. M., \& Bus, J. S. (2013). Cancer mortality of workers exposed to styrene in the US reinforced plastics and composite industry. Epidemiology, 195-203.

5. Abou El-Enein, N. Y., \& El Mahdy, H. M. (2011). Standard precautions: a KAP study among nurses in the dialysis unit in a University Hospital in Alexandria, Egypt. The Journal of the Egyptian Public Health Association, 86(1 and 2), 3-10.

6. Gerlovich, J. A., Wilson, E., \& Parsa, R. (1998). Safety issues and Iowa science teachers. Journal of the Iowa Academy of Science: JIAS, 105(4), 152-157.

7. Gerlovich, J. A., Whitsett, J., Lee, S., \& Parsa, R. (2001). Surveying safety. The science teacher, 68(4), 31.

8. Gunstone, R. F. (1991). Reconstructing theory from practical experience. Practical science, 67-77.

9. Hagelberg, R. R., \& Dombrowski, J. M. (1987). What Research Says: A Survey of Safety in High School Science Laboratories in Arizona. School Science and Mathematics, 87(4), 328-344.

10. Joshua, M. T. a. B., B.A. (2004). Teachers' perception of students evaluation of teaching effectiveness An Online Journal of the African Educational Research Network, The African Symposium. (Vol. 4) 35- 46.

11. Kouzov, O., \& Pavlova, D. Unchain the education through mobility. In UNESCO International Workshop (p. 29).

12. Lazarowitz, R., \& Tamir, P. (1994). Research on using laboratory instruction in science. Handbook of research on science teaching and learning, 94-130.

13. Lunetta, V. N. (1998). The school science laboratory: Historical perspectives and contexts for contemporary teaching. International handbook of science education, 1, 249-262.

14. Malik, S., Ajaz, N., \& Jumani, N. B. (2016). Professional Knowledge, Attitude and Practice of Teachers. Pakistan Journal of Social Sciences (PJSS), 36(1), 199-208.

15. MOE, Minstery of Education -Palestine. Annual Educational Statistics 2019/2020,(2019). (https://www.mohe.ps/home/cms/uploads/2020

16. Olson, S., \& Loucks-Horsley, S. (2000). Inquiry and the National Science Education Standards: A guide for teaching and learning. Washington, DC: National Academies Press.

17. Papanastasiou, E. C. (2001). Willingness to follow math-related careers among seniors in math classes: The case of Cyprus. Science Education International, 13(2), 20-21.

18. Peñas, F. J., Barona, A., Elías, A., \& Olazar, M. (2006). Implementation of industrial health and safety in chemical engineering teaching laboratories. Journal of Chemical Health \& Safety, 13(2), 19-23.

19. Pisaniello, D. L., Stewart, S. K., Jahan, N., Pisaniello, S. L., Winefield, H., \& Braunack-Mayer, A. (2013). The role of high schools in introductory occupational safety education-Teacher perspectives on effectiveness. Safety science, 55, 53-61. 
Volume4 : Issue 1, October, 2020

20. Plohocki, B. A. (1998). National Chemistry Teacher Safety Survey.

21. Reisen, F., \& Brown, S. K. (2009). Australian firefighters' exposure to air toxics during bushfire burns of autumn 2005 and 2006. Environment International, 35(2), 342-352.

22. Seki, A., Takehara, H., Takigawa, T., Hidehira, T., Nakayama, S., Usamt, M., ... \& Kira, S. (2001). Use of material safety data sheets at workplaces handling harmful substances in Okayama, Japan. Journal of occupational health, 43(2), 95-100.

23. Stallings, C., Gerlovich, J., \& Parsa, R. (2001). Science safety: A status report in North Carolina schools. The Science Reflector, 30(3), 11-12.

24. Stephenson, A. L., West, S. S., Westerlund, J. F., \& Nelson, N. C. (2003). An analysis of incident/accident reports from the Texas Secondary School Science Safety Survey, 2001. School Science and Mathematics, 103(6), 293-303.

25. Versweyveld, J. (1999). Trends in laboratory safety. Canadian Chemical News, 51, 18-18.

26. Walker, C. (1999). Lab safety, how it happens at MAXXAM analytics. Can Chem News, 19-21.

27. Ward, S., \& West, S. (1990). Accident in high school chemistry labs. The Texas Science Teacher, 19(2), 14-19.

28. Wiediger, S. D., \& Hutchinson, J. S. (2002). The significance of accurate student self-assessment in understanding of chemical concepts. Journal of chemical education, 79(1), 120.

29. WHO, World Health Organization (2004). International Programme On Chemical Safety: Guidelines On The Prevention Of Toxic Exposures Education And Public Awareness Activities. Geneva: World Health Organization.

30. WHO, World Health Organization. (2009) Children's Health and the Environment. WHO Training Package for the Health Sector-World Health Organization. http://www. who. int/ceh.

31. Young, J. R. (1970). A survey of safety in high school chemistry laboratories of Illinois. Journal of Chemical Education, 47(12), A829. 